\title{
An Exploration of Causes of Saudi Students' Reluctance to Participate in the English Language Classroom
}

\author{
Arafat Hamouda \\ Department of English language and Translation \\ Faculty of Arabic Language and Social Studies \\ Qassim University, Qassim, Saudi Arabia \\ Tel: 96-650-365-4413_E-mail: arafathamouda77@Gmail.com
}

Received: October 22, 2012 Accepted: November 8, 2012 Published: November 9, 2012

doi:10.5296/ijele.v1i1.2652 URL: http://dx.doi.org/10.5296/ijele.v1i1.2652

\begin{abstract}
EFL learners' reluctance to speak English in the classroom is a problem commonly found in a foreign language context. This study attempts to investigate the causes of the nonparticipation of students in EFL classrooms in a key university in Qassim, Saudi Arabia. One hundred, fifty-nine first-year non-English majors answered a 66-item questionnaire on reticence. The research findings indicate that a considerable number of students were reluctant to respond to the teacher and remained silent in oral English language classrooms due to many causes such as low English proficiency, fear of speaking in front of others, negative evaluation, shyness, lack of confidence and preparation, and fear of making mistakes. The study also indicated some strategies used by students to participate in the class such as rehearsing what they say and preparing the ideas and questions. Based on the findings, pedagogical implications are discussed with the aim of enhancing the teaching and learning of spoken English in foreign-language contexts.
\end{abstract}

Keywords: reluctance, participation, anxiety 


\section{Introduction}

None can deny that active classroom participation played an important role in the success of language learning (Tatar, 2005). As involvement and participation are essential for language acquisition, the more utterances the learners offer, the better their spoken language is and vice versa. This phenomenon is termed Matthew Effect, that is "rich get richer, poor get poorer" (Chau, Fung-ming, 1996). When students produce the language that they are studying, they are testing out the hypotheses which they have formed about the language. When they respond to the teacher's or other students' questions, raise queries, and give comments, they are actively involved in the negotiation of comprehensible input and the formulation of comprehensible output, which are essential to language acquisition. Students, who are actively involved, reported higher satisfaction and higher persistence rates (Tsui 1996: 146). The importance of learner participation is also stressed by Jackson (2002) who contends that participation provides the setting in which students can construct and shape identities as members of the classroom. Moreover, research has shown that participation in classroom activities is important in order for effective learning to take place (Tsui, 1996).

The linkage between classroom participation and students' academic achievement is undeniable. A study by Liu (2005) finds that students who participate actively tend to have better academic achievement compared to students who do not participate. Students' oral participation can help students fill the gap between what they want to say and whether they are able to say it. Furthermore, it is a common belief that "participation in verbal interaction offers language learners the opportunity to follow up on new words and structures to which they have been exposed during language lessons and to practice them in context" (Liu, 2005). In spite of the growing expectation for verbal classroom participation in second- and foreign-language learning situations, reticence research has captured the attention of language theorists and educators in recent decades (MacIntyre et al., 2001; Tsui, 1996; Biggs \& Moore, 1993; Liu, 2005; Van den Branden, Bygate, \& Norris, 2009). By way of interviews, observations and questionnaires, research has demonstrated that engaging in classroom discussions is one of the most problematic areas for students, as identified by both teachers and students themselves (Kim, 2006). Second/foreign-language learners, especially Asian learners often seem passive and reticent in language classrooms. Students often do not respond to teachers' questions and they do not volunteer answers or initiate questions. They tend to speak Arabic whenever the teacher is out of earshot. Teachers also recognize the fact that students will not produce answers unless they are called on. It is not surprising to find out that students often know the answers, but just do not want to volunteer to say them. They are reluctant to participate in classroom discussions. Some rarely respond to their teachers or actively participate in discussions. What accounts for this phenomenon? What can be done to help students take a more active role?

From his observation and experience of teaching the EFL speaking skills for more than 15 years, however, the researcher has noticed that most of the students who enroll in the English Department of Qassim University have serious deficiencies in speaking skills. This is especially observable when the students take the course entitled "Listening and Speaking Skills" (ENG 121) at first year level. The researcher observed that many students performed 
poorly in this course. Non English major students in Saudi Arabia, similar to learners in foreign language contexts (Jackson, 2002; Howritz et al, 1986), have been observed to be either quiet or to speak English with a trembling voice, make numerous unnecessary stops, or having shaking hands or legs, etc. during English lessons or oral English tests (cortazzi and jin, 1996). This problem was noticed even by other instructors who were offering the same course to different groups. The same problem has also been observed in many SL/FL countries. It has been found that many SL/FL students, especially Asian learners, are passive in language classrooms and choose not to use the target language most of the time, especially when responding to teachers (Cortazzi \& Jin, 1996; Tsui, 1996). As a result, both teachers and students have become frustrated and often complain about the quality of the learning outcome. This makes it urgent to examine this phenomenon to better understand the causes of the students' reluctance to participate in the English language classroom and ultimately enhance the learning and teaching of oral English there.

\section{Research Objectives}

The objectives of this study are two-fold: First, this study intends to better understand the causes of students' reluctance and passivity to participate in English classroom discussions. Second, the study aims to present the strategies used by the students to participate in the classroom.

\section{Research Questions}

The present study attempts to find answers for the following questions:

1. What are the causes of students' reluctance and passivity to participate in English classroom discussions?

2. What are the strategies used by the students to participate in the classroom?

3. Are there any implications for overcoming these obstacles of students' reluctance to participate and interact with one another in class discussions?

\section{The Significance of the Study}

The findings of this study will try to shed light on the causes of students' poor participation in EFL classes at Qassim University in order to help teachers be aware of the factors that lead to non-participation in the class so that they can cope with this problem. Furthermore, the findings could enable teachers to develop approaches and practices for working with EFL students. Finally, they could help educators in developing the future curriculum by taking into consideration the psycholinguistic factors in teaching.

\section{Research Methodology}

\subsection{Subjects}

The subject pool of the study was limited to non-English EFL majors at Qassim University who found it difficult to participate in English classes. The population of this study consisted of 159 of university ENG 101 students from the preparatory year program enrolled in an 


\section{MInstitute Macrothink $_{\text {Int }}$}

English Listening \& Speaking course who attended the first semester of the year 2010-2011. The participants were recruited to answer a battery of questionnaires. In order to explore further the issue of reticence in classrooms, three classes that answered the survey were selected for closer scrutiny.

\section{Research Tool}

\subsection{Questionnaire}

The researcher used a questionnaire in order to investigate the causes that lead to students' reticence in EFL classroom. The questionnaire used in this study consisted of 66-items extracted from instruments used in previous studies (Tahar, 2005; Liu, 2005; Sayadi, 2007). The questionnaire was divided into two sections, Section A, and Section B. As for Section A, there were fifty eight questions asking the respondents about the causes of their non-participation in the class. Section B, on the other hand, tried to investigate the strategies used by the participants when participating. The researcher distributed 159 questionnaires randomly and read the items in front of the students to see if there were unclear items. The instructions of the questionnaire were easy to follow. All the questions were clear. The subjects responded to the English version on a 2-point Likert scale (1=disagree; 2 =agree).

\subsection{Validation of the Instrument}

To ensure content validity, the researcher discussed the problem with English teachers who have had experience in teaching English and then distributed the questionnaire to four referees from the College of Arabic Language and Social studies at Qassim University who are experts in this area. They were asked to judge the appropriateness of each item for the overall purpose of the study. Some of them suggested some modifications in the arrangements of some items which the researcher took into account.

\subsection{The reliability of the Instrument}

The reliability of the study was calculated using the Cronbach Alpha formula. Accordingly, the reliability coefficient was 0.89 which fitted the purpose of the study.

\subsection{Analyzing the Data Obtained from the Questionnaire}

To analyze the data obtained from the questionnaire, the Statistics Package for Social Sciences (SPSS) software was used. For Section A, the data obtained were converted into frequency and later into percentage. The computed data will be represented in tables.

\section{Results and Discussion}

Results to research question 1-"What are the causes that lead to students' reluctance and passivity to participate in EFL classroom?"

The subsequent part of this study has been devoted to the first Question "What are the causes that lead to non-participation in EFL classroom?". To answer this question, the researcher used the percentages for each of the items. Table (1) shows the frequency and percentages of 


\section{MInstitute Macrothink $_{\text {Ins }}$}

the students' responses for the items regarding the causes of the non-participation of students in the EFL class.

Table 1. Causes of non-participation

\begin{tabular}{|c|c|c|c|c|}
\hline Causes of non-participation & No. c & f stude & & \\
\hline Statements & A & $\%$ & $\mathrm{D}$ & $\%$ \\
\hline $\begin{array}{l}\text { 1. I get tense and nervous when I am speaking English in front of the } \\
\text { whole class. }\end{array}$ & 102 & 64.2 & 57 & 35.8 \\
\hline $\begin{array}{l}\text { 2. I feel my heart pounding when I am called upon to answer a question in } \\
\text { English class. }\end{array}$ & 108 & 67.92 & 51 & 33.08 \\
\hline 3. I talk less because I am shy. & 78 & 49 & 81 & 51 \\
\hline 4. I feel too nervous to ask the instructor a question during English class. & 60 & 37.73 & 99 & 62.27 \\
\hline $\begin{array}{l}\text { 5. I am too afraid to volunteer answers to the teacher's question because } \\
\text { my classmates would laugh at me if my answer was wrong. }\end{array}$ & 66 & 41.51 & 93 & 48.49 \\
\hline $\begin{array}{l}\text { 6. It is unpleasant speaking English in class because my mistakes make me } \\
\text { feel incompetent. }\end{array}$ & 85 & 53.46 & 74 & 46.54 \\
\hline $\begin{array}{l}\text { 7. I am 'afraid of being seen as foolish if I make too many mistakes when I } \\
\text { speak in class. }\end{array}$ & 108 & 67.92 & 51 & 33.08 \\
\hline 8. I am 'afraid of making mistakes in front of my classmates. & 80 & 50.31 & 79 & 49.69 \\
\hline 9. I am afraid others will laugh at me if I make some mistakes & 66 & 41.51 & 93 & 48.49 \\
\hline $\begin{array}{l}\text { 10. I am afraid of making mistakes in front of my teacher because this will } \\
\text { influence the end-of-course results. }\end{array}$ & 110 & 69.18 & 49 & 30.82 \\
\hline $\begin{array}{l}\text { 11. I feel anxiety if I am corrected while speaking English in front of the } \\
\text { whole class. }\end{array}$ & 88 & 55.34 & 71 & 44.66 \\
\hline $\begin{array}{l}\text { 12. I feel more anxiety in the class because my teacher always corrects me } \\
\text { in a very bad way. }\end{array}$ & 66 & 41.51 & 93 & 48.49 \\
\hline $\begin{array}{l}\text { 13. To avoid any embarrassing situation, I prefer to remain silent rather } \\
\text { than to orally participate in the classroom. }\end{array}$ & 105 & 66 & 54 & 34 \\
\hline 14. I feel a bit nervous if I sit at the front of the class. & 78 & 49 & 81 & 51 \\
\hline 15. I sit in front if I prepare my homework. & 99 & 62.26 & 60 & 37.74 \\
\hline $\begin{array}{l}\text { 16. In order not to participate in the English class, I like to sit at the back } \\
\text { rows. }\end{array}$ & 74 & 46.45 & 85 & 53.46 \\
\hline $\begin{array}{l}\text { 17. I get nervous when the teacher asks questions which I have not } \\
\text { prepared in advance. }\end{array}$ & 78 & 49 & 81 & 51 \\
\hline $\begin{array}{l}\text { 18. I start to panic when I have to speak without preparation in the English } \\
\text { class. }\end{array}$ & 54 & 34 & 105 & 66 \\
\hline 19. It frightens me when I don't understand what the teacher is saving & 108 & 67.92 & 51 & 33.08 \\
\hline 20. I get upset when I don't understand what the teacher is correcting" & 77 & 48.43 & 82 & 51.57 \\
\hline 21. I get upset when I don't understand what I am saying. & 87 & 54.72 & 72 & 45.28 \\
\hline $\begin{array}{l}\text { 22. Ifeel anxious when I make English oral presentations in front of the } \\
\text { class. }\end{array}$ & 132 & 88 & 27 & 12 \\
\hline 23. I feel more anxious during oral tests in my English class. & 108 & 67.92 & 51 & 33.08 \\
\hline 24. The more I study for the oral language test, the more worried I get. & 60 & 37.73 & 99 & 62.27 \\
\hline 25. My English language is not good. & 120 & 75.47 & 39 & 24.53 \\
\hline 26. I always feel that the other students speak English better than I do. & 54 & 34 & 105 & 66 \\
\hline $\begin{array}{l}\text { 27. I am afraid that other students laugh at me when I speak up English in } \\
\text { the class. }\end{array}$ & 87 & 54.72 & 72 & 45.28 \\
\hline $\begin{array}{l}\text { 28. I am worried about what opinion other students might have of me } \\
\text { when I speak English in class. }\end{array}$ & 77 & 48.43 & 82 & 51.57 \\
\hline 29. I feel anxiety because I have no confidence in my spoken English. & 125 & 78.62 & 34 & 21.38 \\
\hline $\begin{array}{l}\text { 30. I never feel quite sure of myself when I am speaking English in my } \\
\text { class. }\end{array}$ & 87 & 54.72 & 72 & 45.28 \\
\hline 31. I shall only talk when I am very sure what I utter is correct. & 78 & 49 & 81 & 51 \\
\hline $\begin{array}{l}\text { 32.I am reluctant to participate in class because I am afraid of my teacher' } \\
\text { harsh comments and negative gestures }\end{array}$ & 120 & 75.47 & 39 & 24.53 \\
\hline $\begin{array}{l}\text { 33. I feel anxiety because my teacher doesn't give me the needed time to } \\
\text { process the questions that he asked. }\end{array}$ & 82 & 51.57 & 77 & 48.43 \\
\hline
\end{tabular}




\begin{tabular}{|c|c|c|c|c|}
\hline 34. I do not practice English due to big class size. & 108 & 67.92 & 51 & 33.08 \\
\hline 35. I like to participate in a small and comfortable class. & 104 & 65.41 & 55 & 34.59 \\
\hline 36. I get anxious if my teacher puts marks for participation. & 112 & 70.44 & 47 & 29.56 \\
\hline $\begin{array}{l}\text { 37. I feel worried that I can't speak English well, my teacher will get a bad } \\
\text { impression of me. }\end{array}$ & 87 & 54.72 & 72 & 45.28 \\
\hline $\begin{array}{l}\text { 38. I feel apprehensive to participate in the class discussion if the lesson } \\
\text { does not interest me. }\end{array}$ & 55 & 34.59 & 104 & 65.41 \\
\hline $\begin{array}{l}\text { 39. I am reluctant to participate in the class discussion because I am not } \\
\text { interested in English. }\end{array}$ & 82 & 51.57 & 77 & 48.43 \\
\hline 40. I think what keeps me reticent is my poor English proficiency. & 120 & 75.47 & 39 & 24.53 \\
\hline $\begin{array}{l}\text { 41. I am reluctant to participate because I can't respond quickly and } \\
\text { fluently. }\end{array}$ & 118 & 74.21 & 41 & 25.79 \\
\hline $\begin{array}{l}\text { 42.I get anxious to participate because I can't speak in complete sentences } \\
\text { (i.e. uttering words or broken English) }\end{array}$ & 89 & 55.97 & 70 & 44.03 \\
\hline 43. I can't participate because I have difficulty in constructing sentences. & 82 & 51.57 & 77 & 48.43 \\
\hline 44. When I want to speak "I am not sure which tense to use". & 54 & 34 & 105 & 66 \\
\hline $\begin{array}{l}\text { 45.I don't participate because I am scared that I } \\
\text { would make noticeable grammatical errors. }\end{array}$ & 116 & 72.96 & 43 & 27.04 \\
\hline 46. I don't have exact words to express my ideas. & 75 & 47.16 & 84 & 52.84 \\
\hline $\begin{array}{l}\text { 47. I always feel nervous speaking English because I do not have enough } \\
\text { vocabulary to express my ideas. }\end{array}$ & 118 & 74.21 & 41 & 25.79 \\
\hline ed about my pronunciation when I speak in the class. & 114 & 71.70 & 45 & 28.30 \\
\hline rassed if I mispronounced & 89 & 55.97 & 70 & 44.03 \\
\hline $50 . \mathrm{I} 1 \mathrm{c}$ & 118 & 74.21 & 41 & 25.79 \\
\hline 51.I don't & 130 & 81.67 & 29 & 18.33 \\
\hline 52. I worried about the consequence of failing English courses & 125 & 78.62 & 34 & 21.38 \\
\hline 53. The allotted time for practicing English in class is not enough. & 111 & 69.81 & 48 & 30.19 \\
\hline $\begin{array}{l}\text { 54. I always feel nervous speaking English because my teacher is very } \\
\text { strict. }\end{array}$ & 75 & 47.16 & 84 & 52.84 \\
\hline 55. I feel relax when my English teacher responds in a friendly way. & 113 & 71.06 & 46 & 28.94 \\
\hline 56. I feel more relaxed in pair work or group work & 100 & 62.89 & 54 & 37.11 \\
\hline $\begin{array}{l}\text { 57. I get bored because of the teaching method that the teacher used in } \\
\text { English class. }\end{array}$ & 104 & 65.41 & 55 & 34.59 \\
\hline 58. I don't like to participate because 1 & 99 & 62.27 & 60 & 37.73 \\
\hline
\end{tabular}

\subsection{Speaking in Front of the Whole Class}

Different activities in the classroom procedure, particularly ones that demand students to speak in front of the whole class, have been found to be the most anxiety provoking. The present study found that $64.2 \%$ of students are afraid of speaking in front of others in class. This finding is similar to that reached by Koch and Terrell (1991) and Young (1991: 429) who found that more than sixty-eight percent of her subjects reported feeling more comfortable when they did not have to get in front of the class to speak.

To speak in front of the whole class is a potentially risky business in many students' eyes. However, students feel a lot better when they are not required to face the whole class.

\subsection{Lack of Preparation}

Lack of preparation is another cause of students 'reticence to participate in English language class. The finding of the present study revealed that $34 \%$ of students feel nervous when speaking English without any preparation whereas 66\% don't. This finding is consistent with that of the Study carried out by Mustaphaa, Nik Abd Rahman, and Yunus 2010 who found lack of preparation, fear of appearing unintelligent to their classmates or instructors, and feeling intimidated make students become less inclined to participate. 
$49 \%$ of participants also get nervous when the teacher asks questions which they have not prepared in advance. However, more students attributed their anxiety to lack of preparation and expressed that they would feel less anxious and more confident to speak English with preparation, similar to those students in Tsui's (1996) study.

\subsection{Calling on Students}

The procedure the teacher used for calling on students was also one of the main sources of anxiety in the class. $67.92 \%$ of students feel their heart pounding when they are called upon to answer a question in English class. This finding is consistent with that reached by Mustaphaa, S.M., Nik Abd Rahman, N. and Yunus, M. (2010) who also finds that students get more anxious when called upon to respond individually, rather than if they are given choice to respond voluntarily.

\subsection{Incomprehensible Input}

One of the reasons why the participants were unable or reluctant to participate was that they did not know what to say' during the class discussions. When asked how they feel when they don't understand what they say, $54.72 \%$ of learners said that they get anxious. The findings of the study revealed that knowing what to say was as important as knowing how to say. In fact, this finding is similar to that reached by Han (2007) who indicated that one of his students in the interview said, "I will only participate if I know what to speak".

Students also agreed with statements "I get upset when I don't understand what the teacher is correcting" Item (20), (48.43\%); and "It frightens me when I don't understand what the teacher is saying, item (21)" (67.92\%). They believed that in order to understand the target language message they must understand every word that was spoken. This finding is similar to that of another study by McCroskey (1992) who also reveals that many Asian students face some difficulties to participate in the discussion.

\subsection{Fear of Volunteering to Ask or Answer a Question in Class}

The issue of being afraid to speak in class for fear of making mistakes was of concern for learners. When asked how they feel concerning asking and answering questions during class, more than third of the participants $(37.73 \%)$ said that they often felt afraid of asking a question to instructors during class. This finding is consistent with that of Liu and Littlewood, 1997 who reported that the learners in their surveys get anxious if they raise comments and questions during English class.

Many students $(41.51 \%)$ are also reluctant to volunteer to speak or to answer a question in class because they are afraid that their answers were wrong'. This finding is similar to another study by Tanveer (2007) who indicate that most of the students were not used to volunteering to speak in class. They were not simply afraid of making mistakes.

\subsection{Shyness}

Shyness was another influencing factor which could affect students' participation. However, shyness, according to McCroskey (1992), is a behavior that could be the result of any one or 
a combination of the following factors: social introversion, unfamiliarity with academic discourse, lacking confidence in subject matter, and/or communication apprehension. The survey conducted in this study as shown in Table (1) revealed that less than half of the respondents (49\%) believed that their shyness had affected their involvement in classroom discussions. The respondents responded that they talk less because they feel shy.

\subsection{Fear of Making Mistakes and Being Laughed at}

Fear of making errors is often cited as another cause of the perceived reticence and passivity. And this anxiety factor is also allegedly related to certain aspects of Eastern culture, such as the desire to be right and perfect and fear of losing face (Cheng, 2000). The findings of this study were in agreement with this respect too. The participants (50.31\%) frequently expressed that they feel afraid, and even panic because of the fear of committing mistakes or errors in front of classmates. 55. 46\% of students expressed their anxiety of making mistakes because they think their mistakes make them feel incompetent.

Moreover, $67.92 \%$ of participant agreed with the statement "I am 'afraid of being seen as foolish if I make too many mistakes when I speak in class. They think this will distort their image in front of their classmates. Fear of being laughed at was one of the causes that contributes to the passivity and reticence of students to participate in the class discussion. More than $41 \%$ of students announce that they don't like to participate in the class discussion because they are afraid of being laughed at.

\subsection{Fear of Negative Teacher Traits}

Negative lecturer traits affect Students' reticence in the classroom discussions. Many past researchers mentioned that negative lecturer traits discourage students' participation (Liu, 2005 and Tanveer, 2007). Similar to the previous studies, the present paper also found that many students mentioned that negative lecturer traits like having poor teaching skills (65.41\%) and being impatient (62.27\%) deter students from participating. The teaching procedure adopted by the teacher may be anxiety-provoking which inhibits students9 participation.

Afraid of being criticized and embarrassed in front of classmates was also one of the factors that contribute to student's unwillingness to take part in classroom Discussions. As such, 66\% of students prefer to remain silent rather than to orally participate in the classroom so as to avoid teacher's criticism and any embarrassing situation. This result is in agreement with Tanveer (2007) who found that students prefer to remain silent or speak in a subdued voice due to their consciousness of their limitation in the new language.

Another negative teacher trait that discourages participation was teacher's harshness and strictness. Around $75.47 \%$ of students agree the statement " I am reluctant to participate in class because I am afraid of my teacher' harsh comments and negative gestures". More than $47.16 \%$ of students expressed that they get more anxious when their teacher is very strict. At the same time, many students $(71.06 \%$ ) reveal that they feel relax when my English teacher responds in a friendly way. 


\subsection{Fear of Negative Teacher Evaluation}

The present study found that fear of negative evaluation was a source of anxiety in the English FL classroom. 54.72\% of students feel worried that they can't speak English well; their teacher will get a bad impression concerning their performance. Students remain reticent because they believe that the teacher evaluates them negatively if they make mistakes. And this perception may probably be due to the teaching attitude and practice the teacher applies.

Not surprisingly, more than two thirds of students $(69.18 \%)$ get more apprehensive about making mistakes in front of teachers because they think it is more likely to influence their end-of-course results. This seems to indicate, as found by Price, 1991, that language anxiety is negatively correlated with language course grades. These findings suggest that assessment type and teachers' attitude towards assessment can significantly contribute to learners' anxiety. It might be beneficial if future research explores this issue in depth, particularly in $\mathrm{L} 2 / \mathrm{FL}$ classroom.

Fear of teacher negative evaluation makes $70.44 \%$ of students at Qassim University like to see no marks for participation. This finding goes in accordance with that reached by Price, 1991) who suggests that undergraduate students may overcome the fear of participating with assessment and may be more self-motivated and hence happy to participate independently, without a system of reward and punishment.

\subsection{Fear of Teacher's Correction}

The results of the studies previously cited indicate that the authoritative, embarrassing and humiliating attitude of the teachers towards students, particularly when they make mistakes, can have severe consequences on learners' cognition and their willingness to communicate in the class (Horwitz et al., 1986; Price, 1991; Tanveer' 2007; Young, 1991). Consistent with the literature on language anxiety, 55.34\% 0f Students expressed their feelings of anxiety if they are corrected while speaking English in front of the whole class. $41.51 \%$ of the participants also feel more anxiety in the class because their teacher always corrects me in a very bad way.

\subsection{Class Arrangement}

Classroom arrangement was also one of the most frequent factors mentioned as influencing students' participation. $49 \%$ of the participants announce that they feel a bit nervous if they sit at the front of the class. $62.62 \%$ of students who liked to contribute in whole-class discussions tended to sit at the front of the class whereas for those $(46.45 \%)$ who usually acted as observant would prefer to sit at the back. $65.41 \%$ of the participants like to participate in a small and comfortable class, whereas 67.92 are reluctant to participate in large class.

\subsection{Lack of Confidence}

Another factor that contributes to the reluctance of students to participate in the class discussion was the lack of confidence in using English as a vehicle for spoken communication. Many students $(78.62 \%)$ don't feel confidence speaking in front of class. 
More than half of students $(54.72 \%)$ expressed their agreement with the statement: "I never feel quite sure of myself when I am speaking English in my class."

Lacking confidence makes them believe their language skills to be weaker than those of others in class.

\subsection{Comparison with Peers}

Many students believed strongly and probably correctly that there was a great difference in English ability between them and their peers. They felt anxious, "uncomfortable," and "envious" because of these perceived differences. The current study showed that more than 34 $\%$ Of students feel more anxious in the FL classroom when that they felt other students were better than themselves. They constantly compared themselves with their classmates, feeling inferior to others. Such negative cognitions put serious impediments in their language development; this lead to heightened awareness of their deficiencies and consequently to reticence when are called upon to exhibit their competence in the target language.

\subsection{Self-esteem}

Another source of students' reluctance to speak spontaneously is self-esteem. Morrison and Thomas (1975) define self-esteem as 'the set of evaluative attitudes that a person has about himself or his accomplishments'. Studies have found that learners' self-esteem has some effects on the students' behaviour in the classroom. For example, Morrison and Thomas (1975) point out those students with low self-esteem say less in class and sit further back in the classroom compared to students with high self-esteem. Young (1990) also finds that learners' affective attitudes to English have a significant effect on their speaking self-rating the more negative the affective attitudes, the lower the self-rating. Similar to these previous findings, the learners in this study $(75.47 \%)$ revealed that they don't really believe their English language is good. They feel a sense of unease speaking English simply because they do not think they are performing well enough.

\subsection{Presentation in the Classroom}

Like discussion in open-class-forum, giving a short talk or presentation in the class has also been reported to be highly anxiety inducing, one which makes the classroom environment more formal and stressful for the learners. The majority of participants (88\%) agreed that speaking in front of the whole class or in public caused anxiety for most of the learners. Thus, the study reinforced the findings of the earlier studies by Koch and Terrell (1991) who found that a large number of their subjects considered oral presentation as the most anxiety-provoking activity in the class.

\subsection{Lack of Practice}

Lack of Practice was another cause of students' reluctance to participate in the class. EFL learners (51.57\%) didn't have much practice of oral English in class due to the limited class time. As a result, lack of practice provoked much anxiety in many students when speaking English to others in class, Tsui's (1996) studies. 


\subsection{Test Anxiety}

An understanding of test anxiety is also pertinent to the discussion of foreign language anxiety. It is also important to note that oral testing has the potential to provoke both test and oral communication anxiety simultaneously in susceptible students (Horwitz et al. 1986: 127). The present study found that fear of negative evaluation was a source of anxiety in the English FL classroom. $67.92 \%$ of students feel more anxious during oral tests. 37.73 of students agree with the statement that" the more I study......the more worries I get".

\subsection{Peer Evaluation}

One of the sources of students' reticence in the classroom discussions was negative peer evaluation. $48.43 \%$ of students are too concerned about their classmates will think of them when they speak English. More than half of students (54.72\%) announce that they don't like to participate in the class discussion because they are afraid of being laughed at. Related to this is anxiety about standing out in a group or the likelihood of making a fool of themselves, especially when they are not confident about their English.

\subsection{Lack of Practice Due Class Size}

The class size is another reason contributing to student reticence as this restrictive pattern is aimed for teacher-centred transmissional approach which in a way undermines student's active participation in expressing views. The present study finds that many students $(67.92 \%)$ attribute their reluctance to participate in the class discussion due to big class size. This finding goes in accordance with the result of Chau, Fung-ming, 1996 who states that the big class size discourages students from expressing views as it is extremely threatening for teenagers to face a large number of people by themselves while speaking a foreign language which they may expose their weaknesses by making mistakes very easily.

\subsection{Lack of Practice Due to Class Time}

Lack of practice due to the limited class time also affects students' reluctance to participate in class. More than $69.81 \%$ of non-English majors report the allotted time for practicing English in class is not enough. They didn't have much practice of oral English in class due to the limited class time. They do not have many choices to speak the language in their daily life. Moreover, some students (51.57\%) feel anxiety because their teacher doesn't give them the needed time to process the questions that he asked. The students were not given enough time to respond. Because of their language, they need more time to think, to put words, to make sentences before they can speak in class (Zainal Abidin Bin Sayadi, 2007).

\subsection{Lack of Interest in English Class}

Lack of interest in topics plays a very important role in students' active participation in classroom activities. According to Zainal Abidin Bin Sayadi (2009) and Wang Ping (2010), "when something isn't interesting, most people are not willing to talk about it, while one can talk as much as he can on his interests". The same finding has been confirmed in this study in which many students $(34.59 \%)$ stated that they felt uninterested in the English topics in the classroom discussions. They did not take part in class discussions if 'the lesson was boring'. 
51.57 of students are reluctant to participate in class discussion because they are not interested in English.

\subsection{Lack of Participation Due to Low English Proficiency}

Low English proficiency was one of the main reasons that lead to reticence in ESL/EFL classes. As $75.47 \%$ of students agree with the statement, "I think what keeps me reticent is my poor English proficiency". The finding of the study is similar to previous studies (Jackson, 2002; And Tsui (1996) who attributed student reticence to low English proficiency.

\subsection{Poor Pronunciation}

In line with the past research, pronunciation appeared to be a big cause of stress for EFL learners in this study. Pronunciation is an important issue across language groups because of its immediate effect on interaction. When you feel somebody does not understand you,

You need to improve your pronunciation within a second, which is often hard and stressful". The issue of pronunciation anxiety has been found to be at higher level among Saudi EFL learners in this study. $71.70 \%$ of Saudi learners get worried about their pronunciation when they speak in the class. $55.97 \%$ of subjects expressed embarrassed if they mispronounced. This finding is similar to that reached by Thaher (2005) who reported that students are afraid of being laughed at or of being criticized by others due to inaccurate pronunciation.

\subsection{Lack of Vocabulary}

Lack of vocabulary was identified as a big source of student reticence in oral English language classrooms. $74.21 \%$ of learners feel nervous speaking English because they do not have enough vocabulary (item, 47). This caused a lot of trouble in talking to each other in English. This result is in accordance with Cortazzi and Jin (1996) who stated that students' poor vocabulary is one of the reasons why students are silent listeners rather than active participants in the oral English classroom. $47.16 \%$ of students also express that they don't have exact words to express their ideas (item, 46). As learners can process only a limited amount of information at one time (Lightbown and Spada, 2006: 39), the subjects (80\%) reported that many words do not come out when they are required to speak in hurry.

\subsection{Grammar}

With regard to linguistic difficulties, grammar in earlier studies has been found to be one of the most important aspects that the ESL/EFL learners find difficult when learning to speak a second/foreign language (Zainal Abidin Bin Sayadi, 2007). The present study found that many students (34\%) agree with the statement "When I want to speak, I am not sure which tense to use". More than two thirds (72.96\%) of students also don't participate because they are scared that they would make noticeable grammatical errors. This finding is similar to another study done by Tanveer (2007) who reported that the students in his study experience grammatical difficulties which can lead to the impression that anxious students are not capable communication in the second language. 


\subsection{Lack of Fluency}

Thaher (2005) argues that inadequate conceptual fluency in English is a major struggle for English as Second Language (ESL) learners. The present study revealed that many Participants (74.21\%) struggled with their language fluency and stated that they are reluctant to participate because they can't respond quickly and fluently. More than $55.97 \%$ of students get anxious to participate because they can't speak in complete sentences.

\subsection{The Lack of Opportunity for Practicing English outside the Classroom}

In accord with the previous research, the subjects expressed that limited exposure to English outside the classroom is a serious obstacle in the development of their communicative competency, which is troubling for FL learners when they are required to speak (see e.g. Lightbown and Spada, 2006: 30). When asked whether they practice English outside the classroom, the majority of the students $(81.67 \%)$ respond that they don't have the opportunity to speak English outside the classroom.

\subsection{Fear of Losing Face in Front of Others}

Fear of losing face, publicly or in front of their classmates through criticizing, caused many students to become anxious when speaking English in class. Causing someone to lose face results in a loss of cooperation and even, in extreme occasions, with subtle retaliation against the professor months after the original action transpired (Liu \& Littlewood, 1997).

In conclusion, both EFL teachers and learners should be aware that reticence is a serious obstacle for achieving fluency in spoken English and that multiple variables contribute to it in language classrooms. More importantly, they should realize the urgent need to search for strategies to help students become more active to speak the target language in oral English classes.

\section{Strategies Used When Participating in Classroom Interactions}

One of the objectives of this study was to find out the strategies used by the respondents when participating in classroom interactions. To elicit the strategies used, the second part of the questionnaire was used. Results from the survey showed that most of the respondents would think carefully and silently rehearse what they have in mind before they could contribute to class discussions. Table 2 shows that out of 159 students, 125 students $(78.62 \%)$ of them 'agreed' to the statement The finding is consistent with another study carried out by Liu (2005) who reported that some students need more time to think and organize their thoughts before they can participate.

The second strategy used by the students was writing down and saying what they have written. By putting the ideas into a written form, the students would feel more confident. The survey carried out showed that $109(77.36 \%)$ of the respondents 'agreed' to the statement that they 'write and then say what they have written'.

The third strategy used by students was asking their friends who were sitting next to them what to say before they could participate. The survey conducted also showed that 102 
$(64.15 \%)$ of the respondents would ask their friends who were sitting next to them what to say before they could participate. The small discussions with their friends, according to the respondents, would enable them to check whether the answers or points they wanted to share to the whole class were correct and to avoid the unnecessary embarrassment. This finding confirms the results of another study conducted by Liu (2005) who reported that for some students, the strategy has enabled them to get some ideas on what to say and to check if what they want to say is correct, they will ask their friends first. One of his students in the interview says:' '...I ask my friend what to say. My friend will tell me and then I will tell the class.'

As mentioned earlier, the respondents believed that knowing what to say was as important as knowing how to say it. Thus, the survey revealed that $128(80.50 \%)$ of the respondents viewed content as the primary concerned when it come to class participation. As such, when participating, $112(70.44 \%)$ of the respondents did not mind if their grammar was wrong (Table 2).

To ensure that they have the necessary knowledge and therefore would be able to contribute to class discussions, some students prepared some notes before the class began. Some students also prepared some questions to be asked during the lessons.

However, the habits of preparing notes and questions before the classes began were not widely practiced by many students. The survey showed that only $78(49.06 \%)$ of the respondents prepared some notes and only 81 (50.94\%) of the respondents prepared some questions to be asked (Refer to Table 2).

The last strategy used by the students was listening to other students' participation in order to improve their linguistic skills. 'The survey conducted also confirmed the point discussed above. As shown in Table 2, out of 159 respondents, 123 (76.71\%) students admitted that they would 'listen to their friends' responses first before they could participate' as one of the strategies when participating in class discussions. This finding is in consonance with reached Tatar (2005) who finds that students listen in order to form their own opinions or ideas on what to contribute to the discussions. According to Liu, this strategy is usually used by students who have inadequate content knowledge. By listening to other students' contributions, a learner has more time to think, form and organize their thoughts.

Table 2. Strategies used by the respondents when participating as obtained from the survey

\begin{tabular}{|l|l|l|l|l|}
\hline $\begin{array}{l}\text { When I } \\
\text { participate }\end{array}$ & A & $\%$ & $\mathrm{D}$ & $\%$ \\
\hline 59. I think carefully about what to say and then say it out loud & 125 & 78.62 & 34 & 21.38 \\
\hline 60. I focus on what to say rather than on the language. & 128 & 80.50 & 31 & 19.50 \\
\hline 61. I do not mind if my grammar is wrong & 112 & 70.44 & 47 & 29.65 \\
\hline 62.I listen to my friends' responses before I participate & 123 & 76.71 & 34 & 23.29 \\
\hline 63. I write and say what I have written. & 109 & 77.36 & 50 & 31.64 \\
\hline $\begin{array}{l}\text { 64. I ask friends sitting next to me what to say before I } \\
\text { participate. }\end{array}$ & 102 & 64.15 & 57 & 35.85 \\
\hline 65. I prepare some notes so that I know what to ask. & 78 & 49.06 & 81 & 50.94 \\
\hline $\begin{array}{l}\text { 66. Before the class begins, I prepare some questions to be } \\
\text { asked during the class }\end{array}$ & 65 & 40.88 & 94 & 59.12 \\
\hline
\end{tabular}




\section{Question 3}

Are there any implications for overcoming these obstacles of students' reticence to participate and interact with one another in class discussions?

Based on the discussion and conclusion, the researcher would like to recommend the following ways to reduce the causes of non-participation in EFL classrooms:-

\subsection{Creating a Warm Atmosphere to Motivate the Students to Learn English}

First, teachers should help students develop a positive image of themselves and others. They should create a warm atmosphere to motivate the students to learn English. This can be accomplished by concentrating on classroom activities, creating problem-solving situations, dealing with language problems through group work and activities and correcting students' errors in a friendly way.

\subsection{Lower Students' Anxiety in the Classroom}

According to Young (1991), teachers can start with finding out what students are anxious about. Then teachers can help them ease some of their irrational fears and teach them strategies such as self-talks and doing relaxation exercises to deal with fears.

\subsection{Use Names Can Be Used in a Friendly and not Threatening Way}

Teachers should help the students to know each other at the beginning of the semester. Names can be used in a friendly and not threatening way in order to bridge the gap between the teacher and their students.

\subsection{Prepare More Topics which Are Related to Student Life}

In addition, as suggested by the participants, English teachers can prepare more topics which are not only interesting but related to student life so that students have the interest in and ability to talk about them in English

\subsection{Introduce Opportunities for Students to Speak English outside the Class}

Opportunities such as English clubs inside and outside the school should be introduced to students. The benefits of and tactics for participation should be clearly explained to them. Classroom activities can also be linked to these club activities. For example, students can be asked in the class to report on their participation in the clubs or they can share their experience with their classmates. More opportunities for speaking English outside the class can also be created. For instance, students can be put into groups to do some projects and if possible, their group work should be recorded. They may also be asked to carry out and record interviews with foreigners who are visiting or living around.

\subsection{Fear of Making Mistakes}

The study also revealed that students were reluctant to take part in discussions for fear of making mistakes. Students should be informed that making mistakes is a part of learning process. Teachers should also encourage students to have the confidence to make mistakes in order to acquire communication skills. Furthermore, as a positive response to students' 
concern over the harsh manner of teachers' error correction, teachers' selection of error correction techniques as Horwitz et al. (1986: 131) recommended, should be based upon instructional philosophy and on reducing defensive reactions in students.

\subsection{Speak and Build up Their Self-confidence}

It also may be advisable for EFL teachers to give even the most reticent students the opportunity to speak and build up their self-confidence in a positive, caring environment (e.g., by facilitating interactive group activities or calling on students in a non threatening manner).

\subsection{Improve the Students' Vocabulary}

The findings of the study suggested that many students were still having problems with the language. Lack of vocabulary and inability to master the English sentence structures were the two problematic areas identified. Thus, it is recommended here that activities to improve the students' vocabulary be planned. Apart from improving the students' communicative skills, language teachers should also focus on the grammatical aspects of the language.

\subsection{Deal with the Problem of Overcrowded Classes}

Teachers should deal with the problem of overcrowded classes by assigning students into small groups so that they will be able to discuss the materials outside of the class time. In addition, working in group enables the good students to help the less proficient students in the language. Groups can also be asked to present the materials they read. The process of preparing for the presentation will provide the students with more opportunities to use the language and improved their linguistic abilities.

\section{Conclusions}

Based on the analyses and discussions in the previous section, it can be concluded that most of the students desire to learn spoken English well and were willing to interact with others in oral English language classrooms. However, due to various reasons such as a lack of practice, low English proficiency, lack of confidence, anxiety, cultural beliefs, personality, and fear of losing face, more than two-thirds of the students remained reluctant to respond to the teacher and kept quiet until singled out to answer questions.

\section{Recommendations for Further Studies}

The findings of the present study suggest a number of various studies for future research. First of all, since this investigation was limited to analyze the sources FL speaking ability through a survey, another study can be conducted to examine the potential sources of this type of anxiety using different data collection procedures, such as interviews, diary writing, and think aloud protocols. This study was conducted with the university students from the ELT department. The scale used in this study can be applied to different groups of students from different language majors, different universities in order to find out whether the two variables are indeed language anxiety- provoking or not. e. A final suggestion for future research is to investigate the sources of FL anxiety for other skills such as reading, writing and listening. Research in this area will shed valuable light on the sources leading to anxiety 
for specific skills and how they can be diminished.

\section{References}

Chau, Fung-ming. (1996). Reticence and anxiety in language classrooms: with regard to F.1 students in a Hong Kong secondary school. Dissertation presented in part fulfilment of the requirements of the degree of M A in Applied Linguistics, the University of Hong Kong

Cortazzi M., \& Jin L. X. (1996). Cultures of learning: Language classrooms in China. In H. Coleman (Ed.), Society and the language classroom (pp. 169-206). Cambridge: Cambridge University Press.

Horwitz, E. K. (1986). Preliminary evidence for the reliability and validity of a foreign language anxiety scale. In Horwitz, E. K., \& D. J. Young (eds.) (1991), Language Anxiety: From Theory and Research to Classroom Implications. Englewood Cliffs, NJ: Prentice Hall.

Horwitz, E. K., \& D. J. Young (eds.) (1991). Language Anxiety: From Theory and Research to Classroom Implications. Englewood Cliffs, NJ: Prentice Hall.

Horwitz, E. K., M. B. Horwitz, \& J. A. Cope. (1986). Foreign language classroom anxiety. In E. K. Horwitz, \& D. J. Young (eds.) (1991), Language Anxiety: From Theory and Research to Classroom Implications. Englewood Cliffs, NJ: Prentice Hall.

Jackson J. (2002). Reticence in second language case discussions: Anxiety and aspirations. System, 30(1), 65-84.

Lightbown, P., \& N. Spada. (2006). How Languages are Learned. Oxford:Oxford University Press.

Liu N., \& Littlewood W. (1997). Why do many students appear reluctant to participate in classroom learning discourse? System, 25(3), 371-384.

Liu, M. (2005). Reticence in Oral English Language Classrooms: A Case Study in China. TESL Reporter, 38(1), 1-16.

Koch, A. S., \& Terrell, T. D. (1991). Affective reactions of foreign language students to natural approach activities and teaching techniques. In Elaine K., Horwitz \& Dolly J. Young (Eds.), Language anxiety: From theory and research to classroom implications (pp.109-126). Englewood Cliffs, NJ: Prentice Hall.

MacIntyre, P. D., Baker, S. C., Clement, R., \& Conrod, S. (2001). Willingness to communicate, social support, and language-learning orientations of immersion students. Studies in Second Language Acquisition, 28, 369-388.

McCroskey, James C. (1992). Reliability and Validity of the Willingness to Communicate Scale. Communication on Quarterly, 40(1), Winter 1992, 16-25.

Morrison, T. L., \& Thomas, D. M. (1975). Self-esteem and classroom participation. The Journal of Educational Research, 68, 374-377.

Mustaphaa, S. M., Nik Abd Rahman, N., \& Yunus, M. (2010). Factors influencing classroom 


\section{Macrothink}

International Journal of English Language Education

ISSN 2325-0887

2013, Vol. 1, No. 1

participation: a case study of Malaysian undergraduate students. Procedia Social and Behavioral Sciences, 1079-1084.

Price, M. L. (1991). The subjective experience of foreign language anxiety: Interviews with highly anxious students. In E. K. Horwitz, \& D. J. Young (Eds.), Language anxiety: From theory and research to classroom implications (pp. 101-108). Englewood Cliffs, NJ: Prentice-Hall.

Thaher, M. (2005). Communication Apprehension Among An- Najah National University Students. An-Najah Univ. J. Res. (H. Sc.), 19(2).

Tanveer, M. (2007). Investigation of the factors that cause language anxiety for ESL/EFL learners in learning speaking skills and the influence it casts on communication in the target language. Unpublished Thesis, Faculty of Education, university of Glasgow.

Tatar, S. (2005). "Why Keep Silent? The Classroom Participation Experiences of Non-Native-English- Speaking Students". Language and Intercultural Communication, 5, 284-293.

Tsui ABM. (1996). Reticence and anxiety in second language learning. In K. M. Bailey, \& D. Nunan (eds.), Voices from the language classroom (pp. 145-167). Cambridge: Cambridge University Press.

Young, D. J. (1991). Creating a low-anxiety classroom environment: What does language anxiety research suggest? The Modern Language Journal, 75, 426-439.

Van den Branden, K., Bygate, M., \& Norris, J. M. (Eds.) (2009). Task-based language teaching: A reader. Amsterdam: John Benjamin Publishing Co.

Zainal Abidin Sayadi. (2007). “An Investigation into First Year Engineering Students' Oral Classroom Participation: A Case Study". Unpublished Master Thesis. Kuala Lumpur, Malaysia: UTM [Universiti Teknologi Malaysia].

Zou M. (2004). EFL learners' perceptions of in-class relationships and their voluntary responses. In Y. Gao (ed.), The social psychology of English learning by Chinese college students (p. 149). Beijing: Foreign Lang. Teach. Res. Press.

\section{Copyright Disclaimer}

Copyright reserved by the author(s).

This article is an open-access article distributed under the terms and conditions of the Creative Commons Attribution license (http://creativecommons.org/licenses/by/3.0/). 